\title{
FRAMEWORK FOR TURKISH COMMERCIAL BANKS TO ENTER THE MICROFINANCE MARKET
}

\author{
*Sudi APAK \\ **Jamaluddin HUSAIN \\ ****Ali Faruk ACIKGOZ \\ **** Erol EREN
}

* Beykent University, Turkey

**Purdue University Calumet, USA

***Namik Kemal University, Turkey

***** Profesor on strategic management Istanbul, Turkey

\begin{abstract}
The current Turkish efforts towards providing improved access to financial resources to the poor are limited to selected government agencies providing microfinance to the poor people on a subsidized basis. For obvious reasons such a practice does not stand a chance of becoming self-sustaining. The alternative involves seeking ways to persuade the private commercial banking industry, with all its competitive capacity and dynamism, to launch microfinance (MF) programs with a variety of financial products as part of their corporate social responsibility (CSR).

This paper seeks to encourage the banking industry to seriously consider embracing MF to assist the poor of the country. The study attempts to develop a systematic set of criteria to not only convince commercial banks about the MF potential, but also to persuade them to seriously try making MF products profitable and self-sustaining, while continuing to help ameliorate poverty. The recommended guidelines and criteria include considerations such as: maturity indifference, use of branch networks, mechanics of allocating funds from existing resources, levels of microcredit per customer, microcredit banking versus collateralized banking, targeting the economically lowest twenty percent of the population, etc.

This study proposes, as a starting point, a mandated requirement for every bank to allocate a certain percentage of its previous year's average profits towards MF. Information is also provided on the successful trend among MF Institutions globally towards becoming self-sustaining, and gradually, even profitable. It is the authors' hope that this study might prove to be an igniting point for jump starting a national effort towards assisting the poor through MF initiatives.
\end{abstract}

Keywords: Poverty Reduction, Microfinance, Commercial Banking, Financial Resources

\section{INTRODUCTION}

Commercial banks in Turkey need to look at offering micro credit to the largest unaddressed segment of the individual finance market: the poor, who do not have adequate access to financial resources. While introducing banking products to the poor can also benefit commercial banks, some questions do arise: (1) what should be the design of these microfinance products and services? (2) Would it be commercially feasible and profitable when the risks include not having any collateral? And (3) even if reasonable profitability may be achievable, can commercial banks make it sustainable? This study tries to answer these questions.

The aim of micro finance (MF) programs worldwide is to reach out to the poor who are left out of formal financial system; as a matter of fact the poor do not have access to financial services provided by commercial banks (Mahjabeen, 2008: 1084).

Policy makers and researchers consider micro credit programs as mediums for poverty alleviation. Such programs can be started and managed by governmental agencies as well. However, government 
managed micro credit programs have unacceptably high default rates ranging as much as $70-80 \%$. Therefore, Hassan and Tufte (2001) have recommended that governments should rather invest in infrastructure which could enable lowering transaction costs. Lower transaction costs would benefit not only Non Governmental Organizations (NGOs) and Microfinance Institutions (MFIs) but also commercial banks to improve their operational efficiency.

Another factor worth looking at is the channels of distribution involved in micro finance operations. For instance, MFIs worldwide have established themselves as a customer aggregation channel, with the proven ability to reach out to the poorest of the poor in most countries. But, they cannot be as effective as multiple service providers like commercial banks which have the greatest potential to provide access of universal financial services (Mor and Ananth, 2008). These financial services may include micro finance (MF) as well.

MFIs are generally known to assert pressure to obtain high repayment rates, while self help groups usually have lower pressure with their development banking focus (Swain and Varghese, 2009: 1675). If a large number of commercial banks were to enter the MF market, these pressures may become balanced since banks would provide not just micro finance products but other financial services as well. For commercial banks MF products would constitute one of many sources of profitability.

Innovations in MF products over the past few decades reveal new and innovative changes to help the poor increase their incomes while reducing vulnerability in the short term (McKee, 2008: 35). Commercial banks generally operate in a highly competitive market and if they were to enter the microfinance segment market it is most likely that they would generate newer services specially designed for the poor.

Many studies in the MF literature have emphasized the need to assess asset accumulation, and have suggested possible impacts, such as, short term consumption, profitability, and consequently individual development. However, Swain and Varghese, (2009), consider asset accumulation as a potential escape from chronic poverty and as a measure of long term sustainable impact. This is one of the strengths of commercial banks in that they can easily evaluate asset accumulation of MF customers by use of bank deposit accounts during the loan period.

This study is to present suggestions on how commercial banks could offer MF products not only for the poor rural populations, as is the worldwide practice, but also to urban populations of developing countries. Most developing countries have urban populations with high unemployment rates leading to reduced access to financial resources. Due to high operating costs, commercial banks usually cannot reach the poor in underdeveloped areas (Hassan and Tufte, 2001:1080). However, commercial banks can offer MF for urban areas where they operate and have strong presence. Thus, lower transaction costs per customer would be helpful in lending to low income households in urban areas.

The two strategic factors in reducing default risks in MF are: (a) repayment of loan installments, and (b) ability to save, in order to reduce default risks. Both factors can be handled if income created by micro credit and savings from such income could be controlled. Today there are various electronic payment and saving mediums, i.e., debit and credit cards issued by most commercial bank and linked to customers' bank deposit accounts. MF can also be linked to such an account to concentrate on repayments and to make the borrower save too. The period of micro credit repayment can be extended and the same amount of microloan be granted at the beginning of each renewed period. Micro credit contracts make individuals, or sponsoring groups, liable for repayment of the loans. Carpena et al., (2010), found evidence that under group liability monthly loan installments were $6 \%$ less likely to be neglected, and compulsory saving deposits were $19 \%$ less likely to be missed, relative to individual liability. Thus, repayments of the installments were found to be risky for individual liability. The only alternative for a financial institution is to control the source of income or the cash flow of the debtor if there are no collaterals as security against the loan.

What if commercial banks could control cash flow of the income source for the borrower to save a minimum amount? Commercial banks have already many sorts of services connected to deposit accounts by which customers can automatically and easily pay loan installments and retain the remaining balance in their deposit account. In urban areas, the network branch and contemporary systems that commercial banks have today are assets for institutionalizing MF. Through effective and 
Journal of Global Strategic Management | V. 7 | N. 1 | 2013-June | isma.info | 5-16 | DOI: 10.20460/JGSM.2013715672

efficient use of these assets, commercial banks may create new systems for sustainable profitability in micro credit services as well.

\section{METHODOLOGY}

This study used multi-source qualitative reasoning and quantitative analyses of secondary data of the Turkish commercial banking industry leading to recommendations on sustainability of micro credit operations. The study used a set of both printed and electronic material consisting of statistics and publications of international and national agencies and the findings were analyzed empirically. All available data and relative figures have been analyzed and compared with world averages.

Though there are barriers to accessing full financial information on the unbanked poor, the study suggests a strategic vehicle for the future role of commercial banks in offering MF products for the benefit of Turkey and other developing countries.

\section{FINDINGS AND DISCUSSIONS}

The total gross savings of any country is considered an indicator or that country's investment potential as well as the potential credit depth for any country. In the case of Turkey, there has been a decrease in gross savings and an increase in the urban population over the past twenty years. Therefore, the need of micro credit for the urban population of Turkey becomes more pronounced.

The World Economic Forum's financial development index ranks Turkey $44^{\text {th }}$ in 2009 compared to rank of $39^{\text {th }}$ in 2008. Its ranking for banking and financial services was $41^{\text {st }}$ in 2009 compared to $38^{\text {th }}$ in 2008. Its ranking in terms of ease of access to loans with a good business plan and no collateral remained at $42^{\text {nd }}$ in the world.

However, in terms of overall ease of access to credit Turkey ranks an impressive $26^{\text {th. }}$ Turkey has about 17.32 commercial bank branches per 100.000 adults and this was ranked as $22^{\text {nd }}-$ both these rankings are impressive and Turkey should capitalize on these positives to strengthen its overall international standing on the financial development index.

Currently the primary provider of MF services in Turkey is state-owned banks, but they are not known to be sufficiently responsive to the overall need for micro credit. Non Governmental Organizations (NGOs) specializing in MF came into existence in Turkey only recently: In 2002 the Maya Foundation for the Support of Women's Work (FSWW) was established, followed by the Turkish Grameen Microcredit Project in 2003. But the fact remains that poor people's need for accessing credit still is unchanged (Gunel and Aytulun, 2006; Karatas and Helvacioglu, 2008). Average savings is considered another macro indicator of the need for microfinance.

Table 1 shows that world average for gross savings during period $1980-2007$, and compares it with Turkey: while the world's total savings remained nearly constant, that of Turkey went down.

\section{Table 1: The percentage change of gross savings, etc., in Turkey and the world,} during past three decades

$\begin{array}{lrrr} & 1980-1990 & 1990-2000 & 2000-2009 \\ \text { Gross Savings in Turkey b (\% of GDP) } & +8.7 & -3.5 & -5.3 \\ \text { World Gross Savings b (\% of GDP) } & -0.2 & -0.3 & \text { No change }^{\mathrm{a}} \\ \text { Total Unemployment Turkey (\% of total labor force) } & -3.2 \mathrm{c} & -1.5 & +2.9 \\ \text { Urban Population in Turkey (\% of total population) } & +15.4 & +5.5 & +4.4\end{array}$

Source: Calculations done on World Bank Data

a The figures up to 2007 were available showing no change between 2000 - 2007. 
Journal of Global Strategic Management | V. 7 | N. 1 | 2013-June | isma.info | 5-16 | DOI: 10.20460/JGSM.2013715672

${ }^{\mathrm{b}}$ Gross Savings were given as a percentage change of Gross Domestic Product (GDP) and were calculated by having the difference of Gross National Income and total consumption plus net transfers.

${ }^{\mathrm{c}}$ Figure refers to the change of available data in between $1985-1990$.

Turkey has some advantages compared to India, as well as globally, in being ranked better than the world averages for amount of time required to start a business. See Table 2 below.

Table 2: World, India \& Turkey comparisons for starting up of a business

\begin{tabular}{|lc|c|c|c|}
\hline & & TURKEY & INDIA & WORLD (b) \\
\hline Ease of doing business index (a) & 2008 & 63 & 132 & \\
Rank of the economy (total 183 countries) & 2012 & 62 & 169 & \\
\hline Time required to start a business & 2008 & 6 & 30 & 38.1 \\
(in days) & 2012 & 6 & 27 & 38.1 \\
\hline Start up procedures to register a & 2008 & 6 & 13 & 8.5 \\
business (No. of procedures required) & 2012 & 6 & 12 & 8.5 \\
\hline
\end{tabular}

Source: World Bank

(a) Easiest regulatory environment available for doing business in an economy that is ranked amongst 183 evaluated economies of the world; (b) world average

World Bank indicators show that the number of individuals or firms listed by a private credit bureau with current information on their loan repayment history, unpaid debts, or credit outstanding have increased in Turkey since 2008.

However, during the same period, Turkey scored a 5.0 on the Credit Depth Information index (Table 3 ) on a scale of 0 to 6 . This index measures the rules that affect the scope, accessibility and quality of credit information available from both private and public registry and resources in a country.

\section{Table 3: Credit Depth Info Index (2004 - 2009); Private \& public credit registry} coverage of Turkey

\begin{tabular}{lllllll} 
TURKISH CREDIT INFORMATION & 2004 & 2005 & 2006 & 2007 & 2008 & 2009 \\
\hline Private credit coverage (\%) ${ }^{\text {a }}$ & 30.0 & 27.6 & n/a & 27.0 & 26.3 & 42.9 \\
Public credit registry coverage (\%) $^{\text {a }}$ & 3.2 & 4.9 & 6.7 & 10.3 & 12.7 & 15.9 \\
Credit depth of information index $^{\text {b }}$ & 5.0 & 5.0 & 5.0 & 5.0 & 5.0 & 5.0
\end{tabular}

Source: World Bank

${ }^{\text {a }}$ Figures were given as a percentage of adult population.

${ }^{\mathrm{b}}$ Index has the values from 0 to 6 where a higher value demonstrates the availability of more credit information to ease lending decisions in the evaluated economy.

n.a. $=$ not available

The World Economic Forum (2008) determined that limited access to financing was the $4^{\text {th }}$ most serious obstacle for doing business in Turkey.

Other World Bank data shows that domestic credit in terms of percentage change in firms using banks to finance investment increased by $38.60 \%$ during the period 2002 to 2008 . Table 4 shows gross 
Journal of Global Strategic Management | V. 7 | N. 1 | 2013-June | isma.info | 5-16 | DOI: 10.20460/JGSM.2013715672 domestic credit issued by the banking sector in Turkey in terms of percentage of the country's GDP has gradually increased over the years, and this is a good sign. This is good sign. However, during the period 1980 to 2009, the total disbursement of loans and grants per capita to promote economic development and welfare in Turkey increased by only $6.80 \%$. Questions arise: Will domestic credit continue to increase in the future? What measures can be undertaken to ensure sustainable increases? Is Microfinance the answer?

Table 4: Domestic credit by banking sector in Turkey as percentages of GDP

\begin{tabular}{lllllll} 
& 2004 & 2005 & 2006 & 2007 & 2008 & 2009 \\
\hline Domestic credit provided $^{*}$ & 42.6 & 46.9 & 45.8 & 49.3 & 52.5 & n.a.
\end{tabular}

Source: World Bank; n.a.= not available

* Net domestic credit facts served by the entire banking industry in Turkey, including all credit to various sectors on a gross basis excluding credit to central government.

Table 5: Long term changes for lowest group's share of income or consumption during 1987 - 2006

\begin{tabular}{llllll} 
& 1987 & 1994 & 2002 & 2005 & 2006 \\
\hline Percentage difference of lowest $^{*} 20$ and $10 \%$ & 3.5 & 3.5 & 3.4 & 3.3 & 3.4
\end{tabular}

Source: World Bank

* Percentage share of income or consumption for the subgroups of population given in deciles.

As Table 5 shows that in Turkey the percentage share of income or consumption for the lowest two groups in deciles has remained almost constant during the period $1987-2006$.

Table 6: Some selected banking sector indicators in Turkey

\begin{tabular}{lcccccc} 
INDICATOR IN YEARS & 2005 & 2006 & 2007 & 2008 & 2009 & $2010^{c}$ \\
\hline Credit growth $^{\mathrm{a}}$ & 57.4 & 40.0 & 30.4 & 28.7 & 32.9 & n.a. \\
Loans as \% of Deposits & 62.2 & 71.2 & 80.0 & 80.8 & 77.6 & n.a. \\
$\begin{array}{l}\text { Percentage of Non-performing loans } \\
\text { Individual consumer \& other loans }\end{array}$ & 4.8 & 3.8 & 3.5 & 3.7 & 5.3 & 4.4 \\
Credit cards $^{\mathrm{b}}$ & 6.7 & 8.3 & 10.7 & 10.3 & 11.1 & 11.3 \\
& 11.8 & 10.4 & 10.1 & 9.3 & 9.5 & 8.8
\end{tabular}

Source: BRSA Financial Markets Reports for Sept-2006, Dec-2006, 2007, 2008, 2009; and June 2010 .

BRSA: Banking Regulation and Supervision Agency of Turkey.

${ }^{a}$ Credit growth figures are given in percentages as compared to the previous year.

${ }^{b}$ Averages of last quarter (December) concentration present the percentage of the given indicator in the total loans or credits granted by the banking sector in that year.

${ }^{\mathrm{c}}$ June 2010 figures were available.

n.a.= Not available.

Table 6 gives some selected banking sector indicators for the last six years as percentage changes in: (a) credit growth, (b) loans to deposits ratio, (c) non-performing loans as a percentage of gross loans 
ratio, (d) share of individual consumer loans and (e) share of credit card loans as a percentage of total credits.

World Bank reports show that in 2007 the share of women employed in the Turkey's nonagricultural sectors as a percentage of total nonagricultural employment was only 21.3 percent during 1990-2003. This does not compare well with the world average of over 35 percent in spite of the fact that the proportion of females in Turkey's population is 0.2 percent higher than the world average. Social policies may, therefore, have to be adjusted towards positive discrimination in order to facilitate their access to credits, including even setting aside a higher percentage of micro credit specifically for females.

With a female labor force participation rate of only 26 percent there is a need to consider better integration of female human capital (Hausmann et al., 2010). In 2010, Turkey was ranked at a lowly $126^{\text {th }}$ position in terms of this gender gap, even though it moved up three places from the previous year. One definite way to bridge this gap would be to facilitate female access to finance. Hausmann et al., (2010) also suggest tracking the gender gap over time. Statistics based on India's similar challenge show that between 2006 and 2010 India was able to increase its female employment percentage by 2.4 whereas Turkey succeeded in a change of only $0.4 \%$ during the same period to time.

The United Nations Development Program (UNDP) has been encouraging the participation of commercial banks in the Turkish microfinance sector by demonstrating the profitability of MFIs and striving to convince banks that the poor can be a profitable segment as well (Gunel and Aytulun, 2006: 162). Other than supporting NGOs, alternate channels need to be created for direct participation of commercial banks.

Micro lending requires initial capital and this need can be covered by the internal units of commercial banks out of their general revenues as well as from the capital reserves of the involved commercial bank (Westley, 2006).

In the banking sector the major source of funding is deposits. However, when the focus is on the short term, maturity structures of deposits do matter. The maturity structure of deposits collected by the banking sector in Turkey is given in Table 7 where the fluctuating characteristic of the "up to one month deposits" can be noticed. Besides, there is a slight and sustained increase for deposits up to three months.

Table 7: Maturity structure of deposits collected by $\&$ percentage changes in the last three years.

\begin{tabular}{lccccc} 
& \multicolumn{3}{c}{$\%$ change } & $\%$ change \\
Maturity of deposits & 2008 & 2009 & $2008-2009$ & $2010 \mathrm{~b}$ & $2009-2010$ \\
Up to 3 months a & 91.2 & 91.9 & +0.77 & 92.5 & +0.65 \\
Up to 1 month a & 31.5 & 27.7 & -12.06 & 30.3 & +9.37
\end{tabular}

Source: Calculations on BRSA Data; Financial Markets Report June 2010.

${ }^{a}$ Last quarter (December) percentage shares within all deposits.

${ }^{\mathrm{b}}$ Figures for June 2010 used.

In order to provide micro loans commercial banks could use their vast network of branches and technological infrastructure. Being under an appropriate legal framework would allow them to operate cost-effectively for the low income population (Delfiner and Peron, 2007: 47). Any imperfections in the financial markets my negatively impact the borrowing ability of the poor. Capital accumulation and entrepreneurial activities are blocked by information asymmetries and transaction costs, especially when the loans are without collateral (Carpena et. al., 2010:1).

Commercial banks can offer different repayment schedules, i.e., daily, bi-weekly, weekly or monthly. If effective interest rates are high enough, commercial banks may be able to grant uncollateralized micro credits, particularly for long term clients with measurable default risks. Because of lengthy and 
Journal of Global Strategic Management | V. 7 | N. 1 | 2013-June | isma.info | 5-16 | DOI: 10.20460/JGSM.2013715672 difficult legal procedures in the case of default, banks may avoid foreclosure of collateral (Baydas, et al., 1997).

The role of commercial banks in MF could evolve in the following ways:

(a) direct lending from existing bank branches,

(b) as a microfinance subsidiary, or

(c) in partnership with an existing Micro Finance Institution (MFI) together with a microfinance fund for securitization (Ugur, 2006:4-15).

Globally very few commercial banks offer MF services, and as such literature and data on the profitability of MF for commercial banks remains nonexistent (Curran et al., 2005). In the European Union (EU) only 45 percent of their population between the ages of 15 - 64 qualifies to start entrepreneurial activities, and of this only 3 to 4 percent are potential users of micro credit. The average amount of a micro loan in EU-15 is $€ 10,240$ and in EU-12 it is $€ ~ 3,800$ with same percentage of risk poverty of $16 \%$ for both (Canale, 2010).

The lowest income group of the population should be considered as the target segment and which constitutes only $3-4$ percent of all potential MF users even in advanced economies. According to Financial Access, (2010), the total amount of loans given in Turkey to small and medium sized enterprises (SMEs), as a percentage of GDP, is only 7.38 percent. In financial outreach figures, the number for branches of commercial banks per 100,000 adults is 17.77 while the figure is only 0.04 for specialized state financial institutions (CGAP, 2010). As such, commercial banks need to be encouraged to enter microfinance in order to take full advantage of the large number of branches that they have.

Commercial banks can use their experiences in making loans to other segments of the market such as the medium-large businesses, to develop alternative models for micro loans and thus create their own individual competitive advantages. Delfiner and Peron (2007) have suggested the inclusion of the following possibilities for banks to consider in exploring newer operating models:

(a) create an internal unit within the commercial bank or branch,

(b) establish a financial subsidiary,

(c) generate relationships with relevant service companies, or

(d) establish strategic alliances with other commercial banks.

Table 8, below, shows selected long-term structural indicators of the commercial banking sector that may be used before implementing this study's recommendations.

\section{Table 8: Some structural indicators of the banking sector in Turkey}

\section{INDICATOR IN YEARS}

Net profit of commercial banks (billion TRL)

Number of commercial bank branches

Individual credits as $\%$ of total credit

(TRL x 000)

Credit per customer (when credit less than 51,000

TRL) TRL x 000 (“A”)

Credit per customer in total credits TRL

TRL x 000 ("B")

Total number of customers credited
Deposit per customer as $\%$ of total deposits

$\begin{array}{rrrrrr}\mathbf{2 0 0 5} & \mathbf{2 0 0 6} & \mathbf{2 0 0 7} & \mathbf{2 0 0 8} & \mathbf{2 0 0 9} & \mathbf{2 0 1 0}^{\mathbf{a}} \\ 5.96 & 8.73 b & 14.86 & 13.42 & 20.18 & 12.17 \\ 6,241 & 6,904 & 7,658 & 8,724 & 8,968 & 9,107 \\ 30.4 & 31.7 & 33.3 & 32.1 & 33.3 & 32.8 \\ 4.0 & 4.0 & 5.0 & \text { n.a. } & 6.7 & 5.3 \\ 2.0 & 3.0 & 3.0 & 3.0 & 3.0 & 3.0 \\ 7.0 & 7.0 & 8.0 & 10.0 & 10.0 & 11.0 \\ 28,863 & 30,685 & 35,403 & 36,693 & \text { n.a. } & \text { n.a. }\end{array}$

Source: BRSA Financial Markets Reports, Sept-2006, Dec-2006, 2007, 2008, 2009; and June 2010.

a June 2010 figures were available.

${ }^{\mathrm{b}}$ Sept-2006 figures were available.

n.a.= Not available; "A" and "B" are explained below. 


\section{RECOMMENDATIONS}

The aim of this study was to generate workable suggestions so that commercial banks could benefit from penetrating the MF sector and attain sustainable and profitable results. To achieve sustained profitability, the following suggestions are offered:

A. (i) The minimum amount of micro credit to be given by each bank branch per customer, referred to as "A", should equal the average size of loan given by that branch per customer in the previous year, in the category of loans of less than 50,000 TRL. The maximum amount of micro loan to be given by that bank branch should not exceed the overall average amount of loan per customer issued during the previous year, referred to as "B". Turkish commercial banks may approve any application for micro credit falling between the minimum and maximum levels suggested above.

Note that the figures "A" and "B" shown in Table- 8 above were computed using data reported by the Turkish banking system authority BRSA, in their periodically issued Financial Markets Reports.

(ii) Total amount of micro-loans to be given at the minimum by any commercial bank branch, referred to as "C", should be calculated as:

$2 \%$ of the average net profit per bank branch location nationally, i.e.,

[(LYNPCB) / (Number of bank branches nationally) $x$ 0.02]

Where $L Y N P C B$ stands for "Last Year's Net Profit for the Commercial Bank"

Note: The $2 \%$ factor is inspired from Brazil's successful experience vide Brazilian Act \# 11110 of 2005. Brazil has been using this $2 \%$ factor for their national Oriented Productive Microcredit program. This act mandates Brazilian commercial banks to allocate each year at least $2 \%$ or more of their gross national profits of the previous year to the MFIs. Brazilian MFIs are also allowed to access federal resources of the Workers' Assistance Fund in addition to the mandatory $2 \%$ from commercial banks (Delfiner \& Peron, 2007:41).

(iii) The total amount of micro loans that any commercial bank may issue for any given year, referred to as "D", could then be calculated as:

"D" = ["C" x Number of branches the bank has nationally $]$

See Table 9, below, where the criteria suggested above has been applied, using past national data on Turkish commercial banks - to compute real values of A, B, C, and D.

\section{Minimum}

B.If there is a maturity mismatch in the banking sector of a country, the alternative repayment schedules for micro credits could help eliminate it by reducing the period between maturity of collected deposits and loans issued. Since loan repayment could be made in daily, bi-weekly, weekly or monthly installments, it could justify interest rates being as high as possible, compared to international MFI practices.

C. Improving financial access for people living in rural and urban areas is vital. This can be best done by commercial banks by effectively using their branch network. Non-performing loans can be monitored by the help of ongoing control of the borrower's deposit account, which should be linked directly to the borrower's source of income. This will ensure that borrowers have regular savings to cope with any default risks. The financial development advantage of commercial bank branches will be a starting point, especially for urban areas where branch concentration is naturally higher in the Turkish banking sector.

D. MF banking can be made possible by:

(a) eliminating collaterals,

(b) sharing past profits, and

(c) considering MF as one of their corporate social responsibilities. 
Journal of Global Strategic Management | V. 7 | N. 1 | 2013-June | isma.info | 5-16 | DOI: 10.20460/JGSM.2013715672

Banks can even downscale, if needed, and offer micro lending services with higher interest rates.

At least 2 percent of the previous year's profits should be set aside by commercial banks for MF operations. In any year that a particular commercial bank breaks even or declares a loss, the previous profitable year could be used for setting MF goals. Commercial banks that grant uncollateralized micro credits can retain the borrowers as long term depositors or savers. Because of lengthy and difficult legal foreclosure procedures for defaulted loans, banks may want to avoid collaterals. The savings of any borrower under their control could accumulate in his/her deposit account, and the commercial banks can, therefore, consider the savings as collateral.

E. The targeted market segment should be Turkey's lowest 20 percent income group, especially in urban areas, and that population segment would appreciate increases in credit availability from commercial banks. In Turkey, the variation between income shares of the lowest two groups has remained generally steady in the past (Table 5), and as such, it is recommended that commercial banks considered this as their preferred target segment.

Table 9: Results of calculations, for the suggested strategy, using historical data

$\begin{array}{llllllll} & \text { Formula } & 2005 & 2006 & 2007 & 2008 & 2009 & 2^{2010^{\mathrm{a}}}\end{array}$

\begin{tabular}{|c|c|c|c|c|c|c|c|}
\hline $\begin{array}{l}\text { Credit per customer (when } \\
\text { credit is less than } 51,000 \mathrm{TRL} \\
\text { - TRLx000) }\end{array}$ & & 2.0 & 3.0 & 3.0 & 3.0 & 3.0 & 3.0 \\
\hline $\begin{array}{l}\text { Minimum amount of MC per } \\
\text { customer (TRL) }\end{array}$ & “A" & 2,000 & $\mathbf{3 , 0 0 0}$ & 3,000 & 3,000 & 3,000 & 3,000 \\
\hline $\begin{array}{l}\text { Credit per customer in total } \\
\text { credits nationally (TRL x 000) }\end{array}$ & & 7.0 & 7.0 & 8.0 & 10.0 & 10.0 & 11.0 \\
\hline $\begin{array}{l}\text { Maximum amount of MC per } \\
\text { customer (TRL) }\end{array}$ & “B” & 7,000 & 7,000 & 8,000 & 10,000 & 10,000 & 11,000 \\
\hline $\begin{array}{l}\text { Net profits of all Turkish } \\
\text { commercial banks } \\
\text { TRL) }\end{array}$ & & 5.96 & $8.73^{\mathrm{b}}$ & 14.86 & 13.42 & 20.18 & 12.17 \\
\hline $\begin{array}{l}\text { Number of commercial bank } \\
\text { branches }\end{array}$ & & 6,241 & 6,904 & 7,658 & 8,724 & 8,968 & 9,107 \\
\hline $\begin{array}{l}\text { Minimum total targeted } \\
\text { amount of MC by commercial }\end{array}$ & "C & 19,099 & 25,289 & 38,809 & 30,765 & 45,004 & 26,726 \\
\hline
\end{tabular}

banks per branch (TRL)

Source: Selected data from BRSA Reports, Sept-2006, Dec-2006, 2007, 2008, 2009; and June 2010.

a June 2010 figures were available. ${ }^{\mathrm{b}}$ September 2006 figures were available.

n.a.= Not available; TRL: New Turkish Lira 


\section{Journal of Global Strategic Management | V. 7 | N. 1 | 2013-June | isma.info | 5-16 | DOI: 10.20460/JGSM.2013715672 CONCLUSIONS}

The overall objective of the above listed suggestions is to help commercial banks engage in sustainable MF activities. Along with enhancing the number of clients, socially responsible commercial banks can achieve a distinct competitive advantage by sharing a portion of their profits with unbanked needy people.

Moving away from subsidized government operated microfinance towards making MF a commercial bank activity will require strong encouragement to motivate the banking sector. As a matter of fact, microfinance encompasses both economic and social advantages, and as such, if any Turkish commercial bank could achieve demonstrable sustainability in this arena as per criteria and guidelines suggested in this paper, it could serve as a role model for other banks not only in Turkey but also in other developing countries.

The study has presented criteria for persuading commercial banks to enter the micro credit segment of banking. These criteria are: minimum and maximum levels of micro credit limits per customer, maturity indifference, use of branch network, micro credit banking versus collateral banking, and targeted market segment to be the lowest $20 \%$ income group. The authors believe that these suggestions can enable the private banking sector to find its way to attain sustainability in the microfinance market. Once this achieved, the total set-aside volume of micro credit can be expected to increase over time.

Sharing a portion of profits generated in the previous year can be considered a CSR issue. Funding the unbanked and thus helping alleviate poverty, without incurring losses, will encourage other commercial banks to also consider entering the microfinance segment, and which would be driven by financial considerations.

When commercial banks achieve expected profitability domestically, it is likely that they may have to seek joint ventures abroad for offering microfinance services in other countries. MF should exist not only for the poor living in rural areas but also for those in urban areas.

It is also likely that commercial banks may hesitate to enter the microfinance segment in anticipation of supportive regulations or subsidies. Even when governmental regulations do not change, or if no incentives or encouragements are offered, the authors hope that some commercial banks should go ahead and enter the Turkish micro credit sector directly, using the criteria suggested here.

Another thought would be for different commercial banks to work together by developing a voluntary charter for alleviating poverty. Thereafter, once the process is in place, it is likely that their charter may soon receive support and be regulated by the Banking Regulations and Supervisory Agency (BSRA) of Turkey, in association with other governmental authorities.

One of the limitations of our recommendations is the possibility of certain commercial banks not willing to join the proposed charter, or engage in non-collateralized banking. Another limitation may be the recent central bank's constricting policy of limiting total credit volume increases to control inflationary pressures. However, the national gain from micro credit would be the alleviation of poverty, which probably is a much more noble challenge than that of controlling inflation.

Nevertheless, the conclusions of the study could be a starting point for future research on how to persuade commercial banks to enter the field of microfinance. 


\section{Journal of Global Strategic Management | V. 7 | N. 1 | 2013-June | isma.info | 5-16 | DOI: 10.20460/JGSM.2013715672 REFERENCES}

Baydas, M. M., Graham, D. H. and L. Valenzuela (1997). Commercial banks in microfinance: new actors in the microfinance world, Microenterprise Best Practices, United States Agency for International Development (US AID) funded project of Development Alternatives, Inc., http://www.uncdf.org/mfdl/readings/CommBanks.pdf, retrieved on: 21 Nov 2010.

BRSA Turkey (2010). Financial Markets Reports of BRSA (Banking Regulation and Supervision Agency of Turkey); September 2006, December 2006, 2007, 2008, 2009; and June 2010 Financial Markets Report. (Note: all BRSA Financial Markets Reports are also available online at: http://www.bddk.org.tr)

Canale, R. R. (2010). Microcredit in advanced economies as a "third way": a theoretical reflection, MPRA 21109, Munich Personal RePEc Archive (MPRA), available at: http://www.european microfinance.org/data/file/Librairy/16.pdf,, retrieved on: 21 November 2010.

Carpena, F., Cole, S., Shapiro, J. and B. Zia (2010). Liability structure in small-scale finance: evidence from a natural experiment, The World Bank, Development Research Group, Finance and Private Sector Development Team, Policy Research Working Paper \#5427.

CGAP (2010), Financial Access 2010: the state of financial inclusion through the crisis, CGAP (Consultative Group to assist the Poor), The World Bank Group, available at: http://www.cgap.org/gm/document-1.9.47743/FA_2010_Financial_Access_2010_Rev.pdf, retrieved 26 Oct 2010.

Chowdhury, Anis (2009). Microfinance as a Poverty Reduction Tool - A Critical Assessment, UNDESA Working Paper No. 89, available at http://www.un.org/esa/desa/papers/2009/wp89_2009.pdf

Curran, L., Natilson, N. and R. Young (2005). Case study on profitability of microfinance in commercial banks (Hatton National Bank), United States Agency for International Development (USAID), Development Alternatives, Inc., available at: http://pdf.usaid.gov/pdf_docs/PNADD679.pdf, retrieved on: 23 November 2010.

Delfiner M. and S. Peron (2007). Commercial banks and microfinance, available at: http://mpra.ub.uni-muenchen.de/10229/1/BcosComyMicrofi.pdf, retrieved on: 23 Oct 2010.

Gunel, G. and O. Aytulun (2006). Assistance or subjugation: The impact of micro credit on the poor (Growth and development), International Conference on Human and Economic Resources, Izmir, Turkey, Proceedings book, pp. 151-166.

Hassan, M. K. and R. D. Tufte (2001). The X-Efficiency of a Group-Based Lending Institution: the Case of Grameen Bank. World Development, Vol. 29, No. 6, pp. 1071-1082.

Hausmann, R., Tyson, L. D. and S. Zahidi (2010). The Global Gender Gap Report 2010, World Economic Forum, Geneva, Switzerland.

Husain, J. (2008), Role Of Micro-Finance Institutions In Reducing World Poverty - An Overview. Business Review, Cambridge, Vol. 11, Number 1, pp. 38-42.

Karatas, A. and A. D. Helvacioglu (2008). The microcredit strategies for SMEs in Turkey in the EU harmonization process, $8^{\text {th }}$ Global Conference on Business and Economics, 18-19 October, Florence, Italy.

Available at:

http://www.european-microfinance.org/data/file/abdulmecit-karatas-asli-deniz-helvacioglu-kuyucumicrocredit-turkey.doc; retrieved on: 21 Nov 2010.

Mahjabeen, R. (2008). Microfinancing in Bangladesh: Impact on households, consumption and welfare. Journal of Policy Modeling: Vol. 30, pp. 1083-1092.

McKee, K. (2008). Microfinance: climate change connections. Development Outreach, World Bank Institute, Special Report: April 2008, pp. 35-37. 
Journal of Global Strategic Management | V. 7 | N. 1 | 2013-June | isma.info | 5-16 | DOI: 10.20460/JGSM.2013715672

Mor, N. and B. Ananth (2008). Access to finance and markets as a strategy to address poverty.

Development Outreach, World Bank Institute, Special Report: June 2008, pp. 44-51.

Swain, R. B. and A. Varghese (2009). Does self help group participation lead to asset creation? World Development, Vol. 37, No. 10, pp. 1674-1682.

Ugur, Z. (2006). Commercial banks and microfinance, College of Arts and Sciences, University of Pennsylvania, CUREJ Electronic Journal, Available at:

http://repository.upenn.edu/cgi/viewcontent.cgi?article=1042\&context=curej, retrieved on: 22 October 2010.

Westley, G. D. (2006). Strategies and structures for commercial banks in microfinance, InterAmerican Development Bank Publications, Sustainable Development Department, Best Practices Series, Washington, D. C., Available at: http://idbdocs.iadb.org/wsdocs/getdocument.aspx?docnum=787390; retrieved on 20 Oct 2010.

World Bank (2010). World Bank Country Data: Turkey, India and the World, Available at http://www.worldbank.org, retrieved on: 20 October 2010.

World Economic Forum (2008). The Global Competitiveness Report 2008-2009, Country/Economy Profiles:

Turkey, World Economic Forum, Geneva, Switzerland.

World Economic Forum (2009). The Financial Development Report 2009, World Economic Forum, Geneva, Switzerland; World Economic Forum USA Inc., New York, USA. 